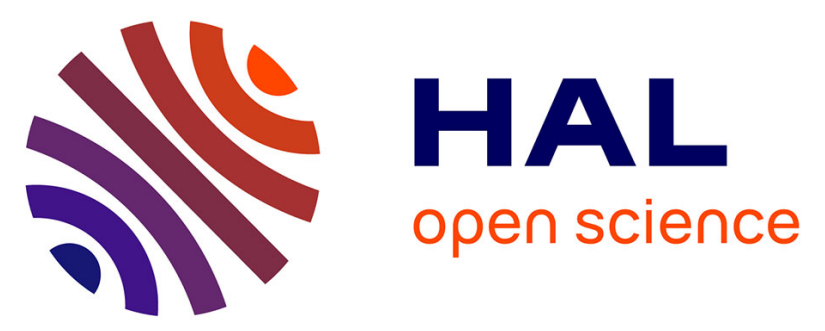

\title{
The feasibility of training with FES-assisted cycling: Psychological, physical and physiological consideration
}

Charles Fattal, Benoît Sijobert, Anne Daubigney, Brigitte Lucas, Christine Azevedo Coste

\section{- To cite this version:}

Charles Fattal, Benoît Sijobert, Anne Daubigney, Brigitte Lucas, Christine Azevedo Coste. The feasibility of training with FES-assisted cycling: Psychological, physical and physiological consideration. Annals of Physical and Rehabilitation Medicine, 2017, 60 (Supplement: 32nd Annual Congress of the French Society of Physical and Rehabilitation Medicine), pp.e15. 10.1016/j.rehab.2017.07.201 . lirmm-01609311

\section{HAL Id: lirmm-01609311 https://hal-lirmm.ccsd.cnrs.fr/lirmm-01609311}

Submitted on 3 Oct 2017

HAL is a multi-disciplinary open access archive for the deposit and dissemination of scientific research documents, whether they are published or not. The documents may come from teaching and research institutions in France or abroad, or from public or private research centers.
L'archive ouverte pluridisciplinaire HAL, est destinée au dépôt et à la diffusion de documents scientifiques de niveau recherche, publiés ou non, émanant des établissements d'enseignement et de recherche français ou étrangers, des laboratoires publics ou privés. 
Keywords Spasticity; Spinal cord injury; Baclofen pump; Complications; Physical activities; Scuba diving

Disclosure of interest The authors have not supplied their declaration of competing interest.

http://dx.doi.org/10.1016/j.rehab.2017.07.097

P062

\section{The feasibility of training with FES-assisted cycling: Psychological, physical and physiological consideration}

Charles Fattal $^{1, *}$, Benoit Sijobert ${ }^{2}$, Anne Daubigney ${ }^{3}$, Brigitte Lucas $^{3}$, Christine Azevedo-Coste ${ }^{2}$

${ }^{1}$ CRF La Chataigneraie, MPR, Menucourt, France

${ }^{2}$ INRIA, CAMIN team, Montpellier, France

${ }^{3}$ CRF COS DIVIO, MPR, Dijon, France

* Corresponding author.

E-mail address: chfattal@yahoo.fr (C. Fattal)

Objective The literature contains considerable data showing that such programs are crucial to reduce the consequences of physical inactivity of people with SCI. The objective of the study was to assess the physical, psychological, functional and financial feasibility of training a paraplegic subject on a FES-assisted recumbent bike - initially fixed on a stationary stand and then over open terrain. At the end of a 12-month training, the patient was invited to participate in an international competition (Cybathlon 2016). Material/Patients and methods Feasibility indicators related to physical, psychological, functional and financial tolerance. Physical, psychological and functional indicators of training impact.
Results Mr. J.P., 47-years-old was paraplegic for 21 years, T3, AIS-A with no zone of partial preservation. Feasibility indicators: no osteoarticular, cutaneous, or cardiorespiratory morbidity was noted. The acceptability score of the training constraints increased from 51 to 59/65 and satisfaction was high around 8/10 and peaked at $10 / 10$ the day after the competition. The pedaling duration increased from 1 to $26^{\prime}$ on the recumbent bike and from $1^{\prime}$ to $15^{\prime}$ on open terrain. The total cost of the bike + the stimulation was estimated at $7650 €$. Impact indicators: no significant changes were found with BMD and the body mass. Thigh circumference did not significantly increase. Cardiorespiratory measures during exercise tests did not show any improvement. SF 36 showed significant improvement of more than $10 \%$ and score on the Rosenberg SelfEsteem Scale rapidly improve from 36 to 39/40 and remained at a level of 40/40 up to the competition. Mr. J.P. distinguished himself during Cybathlon 2016, by reaching the objective of covering $750 \mathrm{~m}$ in under 8 minutes, at an average speed of $5.80 \mathrm{~km} . \mathrm{hr}$ and a maximal speed of $6.14 \mathrm{~km}$.hr. He finished 6th out of 12 .

Discussion/Conclusion A person who has been paraplegic for many years (more than 20) with a high lesion level (T3 AIS-A) can undertake this type of challenge if the prerequisites are met; this type of training is without danger if the safety precautions are respected; the training itself, the challenge of participating in a competition, and the sheer pleasure of cycling outdoors without attracting stigmatizing attention all had a powerful impact on JP's self-esteem and perceived quality of life.

Keywords FES-assisted cycling; Spinal cord injury; Training impact; Feasibility

Disclosure of interest The authors have not supplied their declaration of competing interest.

http://dx.doi.org/10.1016/j.rehab.2017.07.201 